\title{
PENGARUH BOBOT TELUR TETAS ITIK TERHADAP PERKEMBANGAN EMBRIO, FERTILITAS DAN BOBOT TETAS
}

\author{
Sarini paputungan, Lucia J. Lambey*, Linda S. Tangkau, Jaqualine. Laihad
}

Fakultas Peternakan Universitas Sam Ratulangi Manado, 95115

\begin{abstract}
ABSTRAK
Penelitian ini bertujuan untuk memperoleh gambaran perkembangan embrio untuk mengetahui persentase fertilitas dilihat dari bobot telur. Penelitian ini menggunakan 160 butir telur itik dengan rata-rata bobot telur $55 \mathrm{~g} \leq \mathrm{BT}<$ $60 \mathrm{~g}, 61 \mathrm{~g} \leq \mathrm{BT}<65 \mathrm{~g}, 65 \mathrm{~g} \leq \mathrm{BT}<70 \mathrm{~g}$ dan $71 \mathrm{~g} \leq \mathrm{BT}<75 \mathrm{~g}$, dan untuk pengumpulan data dilakukan selama 28 hari sebagaimana lama proses penetasan. Metoden yang digunakan dalam penelititian ini yaitu Rancangan Acak Lengkap, Data yang ada dianalisis secara deskriptif, perlakuan pada penelitian ini yaitu 4 perlakuan 4 ulangan. Variabel yang diukur yaitu persentase fertilitas telur, perkembangan embrio dan bobot tetas. Hasil menunjukan bahwa gambaran perkembangan embrio itik selama proses penetasan baik dan hasil analisis ragam persentase fertilitas menunjukan bahwa perlakuan tidak berbeda nyata $(\mathrm{P}>0,05)$. Hasil penelitian yang dilakukan diperoleh kisaran persetase fertilitas antara 85-90 \%, dan kisaran bobot tetas antara $31 \mathrm{~g}-51 \mathrm{~g}$. Berdasarkan hasil penelitian dapat disimpulkan bobot telur tidak berpengaruh pada proses perkembangan embrio dan fertilitas, tetapi berpengaruh terhadap bobot tetas DOD.
\end{abstract}

Kata Kunci: Bobot Telur Itik, Perkembangan Embrio Itik, Fertilitas dan Bobot Awal DOD

*Korespondensi (corresponding author): Email: lucialambey@yahoo.com
ABSTRACT

EFFECT OF DUCK EGG WEIGHT ON FERTILITY, EMBRYO DEVELOPMENT AND HATCHING WEIGHT OF DAY OLD DUCK. This study was done to evaluate embryonic development for determination of egg fertility and hatching weight of day old duck (DOD). This study involved 160 eggs of duck with the average egg weight (EW) classified into 55g $\leq \mathrm{EW}<60 \mathrm{~g}, 61 \mathrm{~g} \leq$ $\mathrm{EW}<65 \mathrm{~g}, 65 \mathrm{~g} \leq \mathrm{EW}<70 \mathrm{~g}$ and $71 \mathrm{~g} \leq$ EW $<75 \mathrm{~g}$. Data collection was conducted over 28 days, as long as the period of hatching process. The design method used in this study was completely randomized design. Existing data were analyzed using analysis of variance. Treatments in this study were 4 treatments and 4 replications at each treatment. The variables measured were the percentage of egg fertility, embryo development and hatching weight. Results showed that duck embryo development during the hatching process was in good condition process. The results of variance analysis showed that treatments of egg weight did not affect significantly the percentages of egg fertility. The percentages of fertility were ranging between $85-95 \%$. Hatching weights were ranging between $31 \mathrm{~g}-51 \mathrm{~g}$ per DOD. Based on the results of this study, it can be concluded that egg weight had no effect on the process of embryonic development and fertility, except those for the hatching weight of DOD.

Key words: Duck egg weight, embryonic development, fertility, hatching weight. 


\section{PENDAHULUAN}

Itik merupakan jenis unggas air yang memiliki keunggulan daya tahan tubuh lebih baik dibandingkan dengan jenis unggas lainnya. Itik banyak dibudidayakan untuk tujuan memenuhi kurangnya kebutuhan konsumsi protein hewani masyarakat Indonesia. Itik yang dibudidayakan di Indonesia pada umumnya menghasilkan daging dan telur. Itik mulai disukai masyarakat untuk diusahakan sehingga usaha ternak itik semakin berkembang (Lembong 2015). Telur itik dapat menjadi alternatif sumber protein hewani dan disukai banyak orang dari berbagai kalangan.

Itik tidak hanya dinilai kemampuan memproduksi telurnya saja namun juga dinilai dari hasil tetasnya guna menghasilkan bibit baru. Keberhasilan penetasan dapat ditingkatkan dengan bantuan yaitu menggunakan mesin tetas. Mesin tetas membantu upaya mempercepat perkembangan populasi itik dengan memperhatikan proses penetasan yang meliputi setting egg, fertilitas dan kematian embrio. Kualitas telur tetas akan menentukan kualitas bibit yang dihasilkan pada generasi selanjutnya baik dari sisi pertumbuhan maupun produksi telurnya.

Penetasan telur unggas termasuk itik dengan menggunakan mesin tetas, selain memiliki kelebihan yang efektif, murah, dan sangan intensif serta cepat menghasilkan banyak anakan, penggunaan mesin tetas sendiri tidak jarang terjadi kegagalan penetasan konsentrasi gas yang terdapat di dalam telur. Kelembaban berpengaruh terhadap kecepatan hilangnya air dari dalam telur selama inkubasi. Kehilangan air yang banyak menyebabkan keringnya chario-allantoic untuk kemudian digantikan oleh gas-gas, sehingga sering terjadi kematian embrio dan telur membusuk (Baruah et al., 2001). Untuk itu diperlukan pengetahuan yang mendalam dalam melakukan penetasan menggunakan mesin tetas yang tepat dan baik. Selain itu juga diperlukan pengetahuan dan penanganan untuk dapat mengetahui tanda-tanda atau ciri-ciri telur yang infertil atau telur yang terjadi kecacatan saat telah dalam masa penetasan.

Kendala yang sering dihadapi dalam penetasan telur itik, antara lain kematian embrio dan telur yang tidak bertunas atauinfertil umumnya tinggi selama proses penetasan (Baruah et al., 2001; Setioko, 2005). Faktor yang dapat mengakibatkan kematian embrio atau embrio cacat adalah faktor biologis yang menyebabkan spermatozoa tertinggi dalam oviduct dalam waktu lama dan kapasitas sperma yang rendah fertilitasnya. Faktor lingkungan antara lain temperature, kelembaban dan kosentrasi gas yang terdapat didalam telur. Kelembaban 
berpengaruh terhadap kecepatan hilangnya air dari dalam telur selama inkubasi. Kehilangan air yang banyak menyebabkan keringnya chariot-allantoic untuk kemudian digantikan oleh gas-gas sehingga sering terjadi kematian embrio dan telur menjadi busuk.

Faktor-faktor yang mempengaruhi fertilitas telur adalah rasio jantan dan betina, pakan induk, umur penjantan yang digunakan dan umur telur. Selain itu hubungan temperatur lingkungan yang semakin meningkat antara lain temperatur atmosfir disinyalir dapat menyebabkan penurunan fertilitas telur atau sebaliknya. Salah satu cara yang dapat dilakukan untuk mengamati morfologi dari organ tersebut yang mengalami perubahan yang dapat dikenali secara visual atau makroskopis dari setiap tahapan akan digunakan yang telah ditetapkan umur. Penciri-penciri yang dapat dijadikan indikator dalam penetuan umur embrio antara lain terbentuknya garis, lengkungan embrio, pigmen bagian mata, perkembangan sayap dan kaki.

\section{MATERI DAN METODE PENELITIAN}

\section{Waktu Dan Tempat Penelitian}

Penelitian ini dilaksanakan pada tanggal 20 Oktober sampai 16 November
2015 di Laboratorium Jurusan Produksi Ternak Fakultas Peternakan Universitas Sam Ratulangi Manado.

\section{Materi Penelitian}

Telur tetas digunakan sebanyak 160 butir dengan bobot telur $55 \mathrm{~g} \leq \mathrm{BT}<$ $60 \mathrm{~g}, 61 \mathrm{~g} \leq \mathrm{BT}<65 \mathrm{~g}, 65 \mathrm{~g} \leq \mathrm{BT}<70 \mathrm{~g}$ dan $71 \mathrm{~g} \leq \mathrm{BT}<75 \mathrm{~g}$. Peralatan yang digunakan adalah timbangan Electronic kitchen scale stainless steel tray bermerek KrisChef model EK9250 dengan skala ketelitian 0,0 g candler (Alat Peneropongan Telur), mesin tetas semi otomatis 1 unit berkapasitas 160 dengan dilengkapi pemanas yaitu 10 buah lampu pijar 5 watt, cadangan jenset (digunakan jika terjadi pemadaman listrik), alat pengukur panas thermostart, alat pengukur suhu dan kelembaban thermohigro meter, dan bak air yang berukuran $40 \mathrm{~cm} \mathrm{X} 60 \mathrm{~cm} \mathrm{X} 6 \mathrm{~cm}$, suhu yang digunakan $37^{\circ} \mathrm{C}-38^{0} \mathrm{C}$ dengan kelembaban 58\% - 59.7\%.

\section{Metode Penelitian}

Mengsucihamakan mesin tetas, menyiapkan mesin tetas yang telah dirangkai seri menggunakan aliran listrik, mengatur suhu $37^{\circ} \mathrm{C}-38^{\circ} \mathrm{C}$ dan kelembaban $58 \%$ - $59.7 \%$ pada mesin tetas. seleksi telur tetas dan pembersihan telur dengan air hangat, menimbang dan memberi kode pada telur, pemasukan telur kedalam mesin tetas dengan hati-hati, 
setelah telur sudah didalam mesin tetas, semua pentilasi mesin ditutup dan belum bisa dilakukan pemutaran sampai 3 hari kedepan. Pada hari ke-4 dimulai pemutaran, peneropongan dan pemecahan telur pertama untuk melihat perkembangan embrio, pemutaran telur dilakukan $3 \mathrm{x}$ yaitu jam 08.00 malam, 05.00 pagi dan 01.00 siang. Hari ke-8, 12, 16, 20 dilakukan pemutaran, peneropongan, dan pemecahan telur pada setiap perlakuan dan hari ke-24 dilakukan pemutaran, peneropongan dan pemecahan telur yang terakhir untuk melihat kembali perkembangan embrio. Selanjutnya pada hari ke 25 - 28 telur sudah tidak lagi dilakukan pemutaran, peneropongan, dan pemecahan sampai semua menetas, dan DOD ditimbang setelah bulunya kering.

Penelitian terdiri dari 4 perlakuan, setiap perlakuan diulangi sebanyak 4 kali dan setiap ulangan terdiri dari 10 butir telur. Perlakuan bobot telur B1 $(55 \mathrm{~g} \leq \mathrm{BT}$ $<60 \mathrm{~g})$, bobot telur B2 $(61 \mathrm{~g} \leq \mathrm{BT}<65 \mathrm{~g})$, bobot telur B3 $(65 \mathrm{~g} \leq \mathrm{BT}<70 \mathrm{~g})$, bobot telur B4 $(71 \mathrm{~g} \leq \mathrm{BT}<75 \mathrm{~g})$.

\section{Variabel Penelitian}

Variabel yang diukur yaitu perkembangan embrio, tingkat fertilitas telur, dan Bobot Awal DOD.

$\checkmark$ Perkembangan Embrio dan DOD dianalisis secara deskriptif

\author{
$\checkmark$ Fertilitas $=$ \\ $\frac{\text { Telur yang Fertile }}{\text { Telur yang ditetaskan }} X 100 \%$ \\ $\checkmark$ Bobot Awal DOD
}

\section{Analisis Data}

Rancangan penelitian yang digunakan pada percobaan ini adalah Deskriptif dan Metode Rancangan Acak Lengkap (RAL). Selanjunya data yang terkumpul ditabulasi dan dianalisis dengan menggunakan Analisis varians (analysis of variance, ANOVA)

\section{HASIL DAN PEMBAHASAN}

\section{Tahapan Perkembangan Embrio Sesuai Umur}

Perkembangan embrio pada unggas sebagian besar terjadi diluar tubuh induknya. Tahap perkembangan embrio pada unggas umumnya tidak jauh berbeda, dan hanya dibedakan oleh waktu. Tahapan perkembangan embrio dapat dilihat pada gambar-gambar dibawah ini bahwa telur yang ditetaskan secara buatan perkembangan embrionya lebih cepat dibandingkan dengan telur yang ditetaskan di alam. Ini diduga karena pada penetasan buatan suhu dan kelembaban dapat dipertahankan sedangkan pada penetasan alami tidak. 


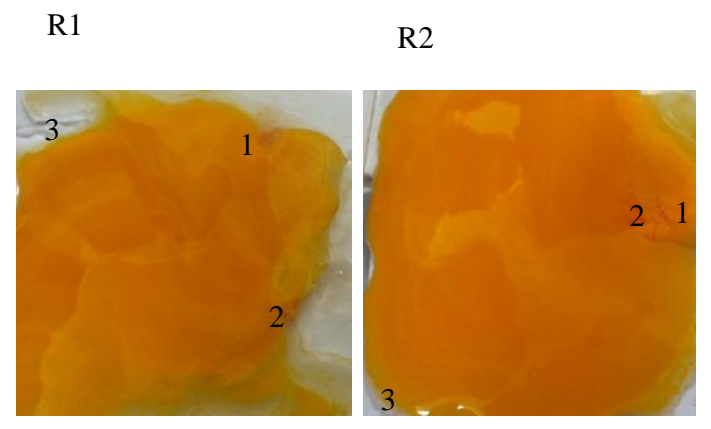

R3

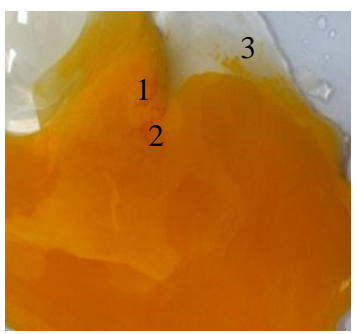

R4

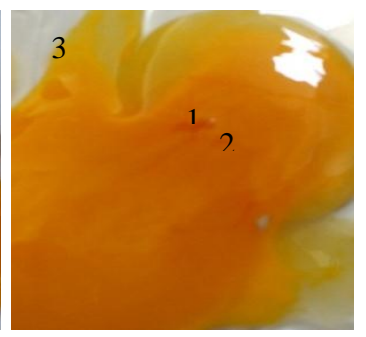

Ket : 1. Bakal Jantung; 2. Pembuluh Darah; 3. Chorion.

Gambar 1. Tahapan Perkembangan Embrio R1, R2, R3 dan R4 Umur 4 Hari.

Tahapan Perkembangan Embrio Itik Umur 4 Hari

Hasil pengamatan tahap perkembangan embrio itik umur 4 hari dapat dilihat pada Gambar 1. Perlakuan R1, R2, R3, R4, memiliki perkembangan embrio yang sama yaitu terlihat bakal jantung (terlihat gerakan denyut jantung) dan penyebaran pembuluh darah pada bagian kuning telur. Adapun perbedaan perkembangan embrio setiap perlakuan hanyalah pada letaknya yaitu R1 dan R3 pembuluh darah dan jantung terletak berbatasan antara chorion dan kuning telur. Sedangkan untuk R2 dan R3, pembuluh darah dan jantung terletak dibagian kuning telur

Menurut Anonimous perkembangan embrio pada ayam umur 4 hari yaitu perkembangan rongga amniotik yang akan mengelilingi embrio, yang berisi cairan amniotik, berfungsi untuk melindungi embrio dan membolehkan embrio bergerak. Nampak gelembung allantois yang berperan utama dalam penyerapan kalsium. Sedangkan menurut Nesheim et al. (1997) pada embrio ayam jantung terlihat berdenyut setelah 30 jam pengeraman dan pembelahan pada otak menunjukan dimulainya pembentukan mata, lubang telinga pada pembentukan bakal ekor. Ekor mulai memendek setelah 51-56 jam dierami dan pada hari ketiga mulai membelok membentuk sudut $90^{\circ}$ dengan axis. Balinsky (1970) mengatakan ada 4 macam selaput yang membungkus embrio yaitu kantung kuning telur, allantois, amnion, dan chorion.

Dibandingkan pernyataan Jull (1951) pada hari ke-2 embrio diselimuti oleh pembungkus yang terdiri dari dua dinding, dinding bagian dalam disebut amnion dan bagian luar chorion. Amnion berisi cairan bening dan kedua lapisan ini berfungsi untuk melindungi embrio dari goncangan mekanis dan mencegah pelekatan embrio melalui aksi jaringan 
Tabel 1. Perkembangan embrio itik umur 4 hari

\begin{tabular}{lcccc}
\hline Penciri umur embrio 4 hari & R1 & R2 & R3 & R4 \\
\hline Penyebaran pembuluh darah & $\checkmark$ & $\checkmark$ & $\checkmark$ & $\checkmark$ \\
Bakal jantung & $\checkmark$ & $\checkmark$ & $\checkmark$ & $\checkmark$ \\
\hline
\end{tabular}

atau pembuluh otot yang berkembang dalam dinding amnion. Allantois merupakan usus belakang embrio, muncul pada hari ketiga. Allantois berfungsi sebagai organ respiorasi, ekskresi ginjal dan menyerap kalsium dari kerabang telur dan albumin dimanfaatkan sebagai bahan makanan selama pertumbuhan dan perkembangan embrio. Sedangkan Winter dan Fuck (1956) menyatakan pada hari ke4 setelah pengeraman bakal kaki dan sayap berkembang. Akhir hari ke-4 masa pengeraman, embrio sudah memiliki organ yang diperlukan untuk berkembang dan umunnya umumnya bagian-bagian tubuh embrio sudah dapat diidentifikasi, namun pada penelitian saya perkembangan embrio hari ke-4 yang baru telihat hanya bakal jantung dan penyebaran pembuluh darah kemungkinan disebabkan perkembangan embrio pada itik lebih lambat dibandingkan dengan perkembangan embrio pada ayam. Penciri perkembangan embrio umur 4 hari dapat dilihat pada Tabel 1.

Hasil dari tabel diatas menjelaskan bahwa perkembangan embrio itik jawa pada masa inkubasi 4 hari ini sudah terlihat penyebaran pembuluh darah dan bakal jatung. Sedangkan pada embrio alabio pada hari ketiga kepala mulai melengkung, hari keempat kepala dan ekor melengkung dan pada mandalung kepala melengkung terjadi pada hari keempat, dan baru pada hari kelima kepala dan ekor melengkung, pada perkembangan antara alabio dan mandalung memiliki selisi 1 hari. Hal ini berbeda dengan penelitian yang saya lakukan pada hari keempat baru terjadi perkembangan bakal jantung dan penyebaran pembuluh darah. Sedangkan pada embrio ayam hari ketiga sudah ada pigmentasi mata (Hamburger dan Hamilton, 1951) dan pada kalkun pigmentasi mata terjadi pada hari ke-5 (Phillips dan Williams, 1994).

\section{Tahapan Perkembangan Embrio Itik Umur 8 Hari}

Pengamatan perkembangan embrio umur 8 hari pada perlakuan R1, R2, R3 dan R4 yaitu dapat dilihat pada Gambar 2 dibawah ini. Embrio sudah nampak jelas 


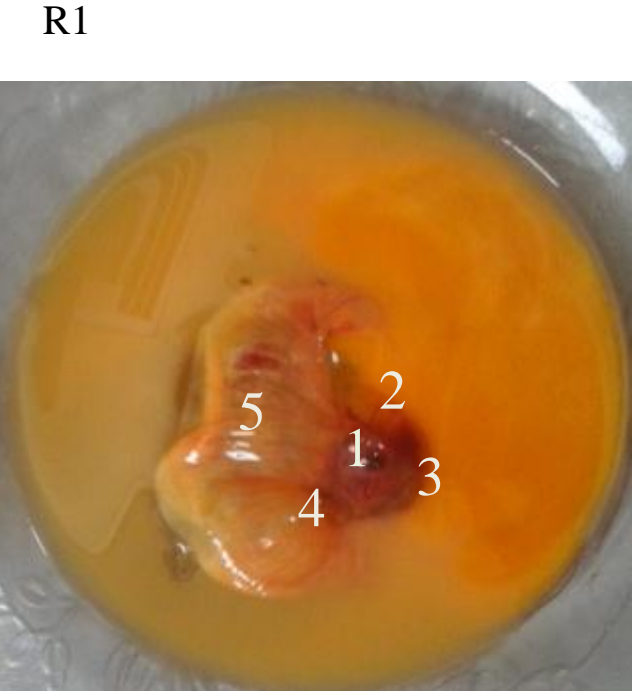

R3

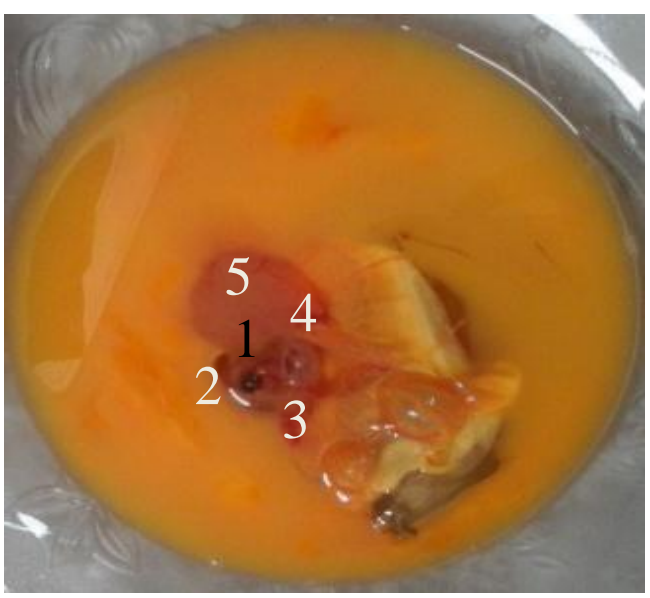

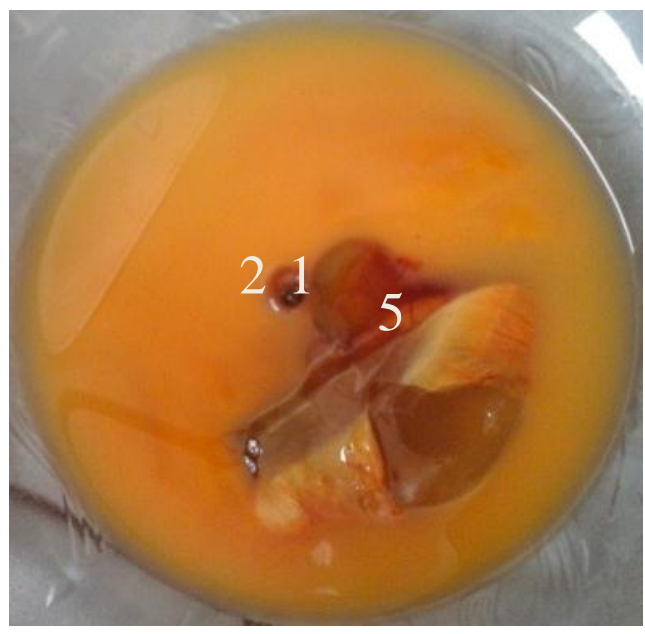

R4

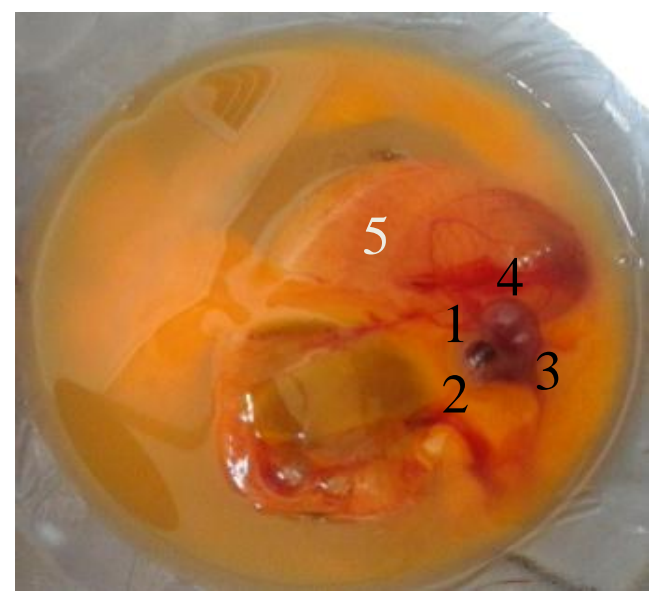

Ket: 1. Mata, 2. Bagian Kepala, 3. Bagian Belakang/ punggung 4. Bagian Ekor, 5. Yolk (Kuning Telur)

Gambar 2. Tahap Perkembangan Embrio R1, R2, R3 dan R4 Umur 8 Hari.

bagian kepala, ekor, bagian belakang dapat dibedakan, mata sudah jelas, dan yolk (kuning telur) mengencer dan terlihat bentuk gumpalan disekitaran embrio itik. hasil pengamatan tahapan perkembangan embrio ke 4 perlakuan umur 8 hari ini yaitu seperti dilihat pada masing-masing gambar di bawah dan keterangannya bahwa perkembangan embrio keempatnya sama, hanya saja pada R2 perkembangan embrio sedikit berbeda karena baru mata yang terlihat bagian tubuh belum bisa dibedakan kemungkinan bagian tubuh dari embrio pada perlakuan R2 ini tertutupi oleh yolk (kuning telur) yang mengencer. 
Tabel 2. Perkembangan embrio itik jawa umur 8 hari

\begin{tabular}{lcccc}
\hline Penciri umur embrio 8 hari & R1 & R2 & R3 & R4 \\
\hline$>$ Pigmentasi mata & $\checkmark$ & $\checkmark$ & $\checkmark$ & $\checkmark$ \\
$>$ Bagian kepala & $\checkmark$ & 0 & $\checkmark$ & $\checkmark$ \\
$>$ Bagian belakang/punggung & & & & \\
$>$ Bagian ekor & $\checkmark$ & 0 & $\checkmark$ & $\checkmark$ \\
\hline
\end{tabular}

Menurut Anonimous (2016) tahapan perkembangan embrio ayam umur 8 hari yaitu membran vetillin menyelimuti (menutupi) hampir seluruh kuning telur, pigmentasi pada mata mulai nampak, bagian paruh atas dan bawah mulai terpisah, demukian juga dengan sayap dan kaki. Leher merenggang dan otak telah berada didalam romgga kepala dan terjadi pembukaan indra pendengar bagian luar. Dibandingkan pernyataan Menurut Sari (2013) embrio ayam umur tujuh hari memiliki yolk sac dengan warna kuning cerah dan bentuk awal yolk sac dapat terlihat jelas. Hal ini dikarnakan yolk belum terserap kedalam yolk sac, sehingga yolk masih terlihat jelas. Amnion brfungsi untuk melindungi embrio agar embrio bisa bergerak bebas, karena terdapat cairan didalamnya. Amniom merupakan pelindung tubuh embrio dibagian dalam dan dibagian luar terlindungi dengan chorion, namun keduanya msih sulit untuk diamati secara terpisah. Embrio pada hari ketujuh ini, memiliki allantois yang berukuran kecil, dikarenakan aktivitas fisiologis embrio masih rendah. Begitu juga albumen pada hari ke-7 masa inkubasi masih terlihat banyak dan tidak kental, hal ini dikarenakan penyerapan nutrisi yang belum maksimal karena embrio masih muda dan nutrisi yang diperlukan embrio masih sedikit. Peebles et al. (2001) menyebutkank bahwa yolk sac dari telur yang dihasilkan oleh induk yang tua beratnya lebih besar dibanding yolk sac yang dihasilkan dari induk muda yang berakibat menurunkan tingkat absorsi yolk dan tingkat perkembangan embrio juga akan menurun.

Menurut Sari (2013) pada hari ke-8 masa pengeraman, bobot kuning telur 
meningkat, disebabkan ada aliran air bahan padatan dari fraksi albunin Ngobbe (2003) pada hari ke-8 mulainya pertumbuhan bulu sampai menutupi mekapus pada embrio itik alabio sedangkan pada mandalung membutukan waktu 10 hari. Dengan demikian dikatakan perkembangan embrio mandalung lebih lambat 2 hari dari alabio.

Pada Tabel 2, dapat dilihat perkembangan embrio itik jawa pada inkubasi hari ke-8 yaitu pada R1 pigmentasi mata sudah terlihat bagian kepala, belakang/punggung dan ekor sudah dapat dibedakan, R2 yang baru terlihat hanyalah pigmentasi mata, sedangkan pada R3 dan R4 perkembangan embrio yang terjadi pada umur 8 hari seperti pada R1. Dibandingkan perkembangan pada alabio pigmentasi-pigmrntasi sudah terlihat jelas pada hari ke-7 sedangkan pada mandalung pigmentasi terlihat jelas pada hari ke-8 antara alabio dan mandalung memiliki selisih perkembangan embrio 1 hari (Nggobe, 2003). Dari hasil perbandingan diatas menjelaskan bahwa perkembangan pada alabio dan mandalung sependapat dengan penelitian perkembangan embrio itik jawa yang saya teliti.

\section{Tahapan Perkembangan Embrio Itik Umur 12 Hari}

Pengamatan tahapan perkembangan embrio umur 12 hari pada perlakuan R1, kekantong kuning telur lewat membrane kuning telur. Sedangkan menurut R2, R3 dan R4 yaitu embrio terlihat sangat sempurna. Pada R1 patuk paruh, mata, sayap, kaki dan ekor sudah terbentuk, pada bagian ekor terlihat bahwa sudah ada folikel bulu halus yang bertumbuh, begitu juga bagian sayap. Pada R2 embrio tertutupi darah oleh sebab itu embrio tidak terlihat dengan jelas. Pada R3 dan R4 embrio terlihat kecil. Dari keempat perlakuan perkembangan embrionya sama, yolk sudah mulai terserap oleh abdomen dan tali pusar sudah terlihat sangat jelas, seperti dilihat pada gambar 6 .

Menurut Anonimous (2016) tahapan perkembangan embrio ayam umur 12 hari yaitu folikel bulu mengelilingi bagian luar indera pendengar meatus dan menutupi kelopak mata bagian atas. Kelopak mata bagian bawah menutupi 2/3 atau bahkan 1/4 bagian kornea. Sedangkan menurut Sari (2013) perkembangan embrio pada masa inkubasi hari ke-12 memiliki ukuran allantois lebih besar disbanding dengan hari ke-7, dikarenakan perkembangan embrio sudah lengkap dan peranan embrio semakin meningkat, maka semakin besar embrio semakin besar pulah kebutuhanya dan besar ekskresi yang dihasilkan makan besar juga area allantois yang dibutuhkan. Allantois pada hari inkubasi ke-14 cukup sulut diamati dikarenakan allantois menyatu dengan 
R1

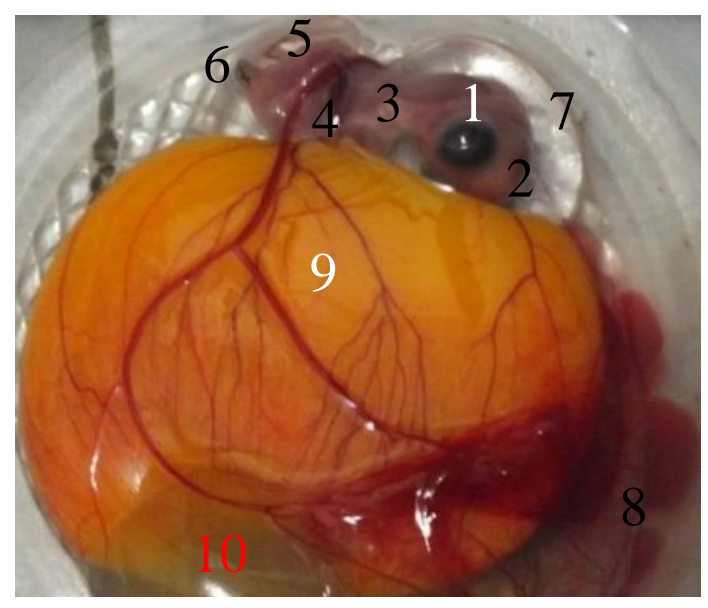

R3

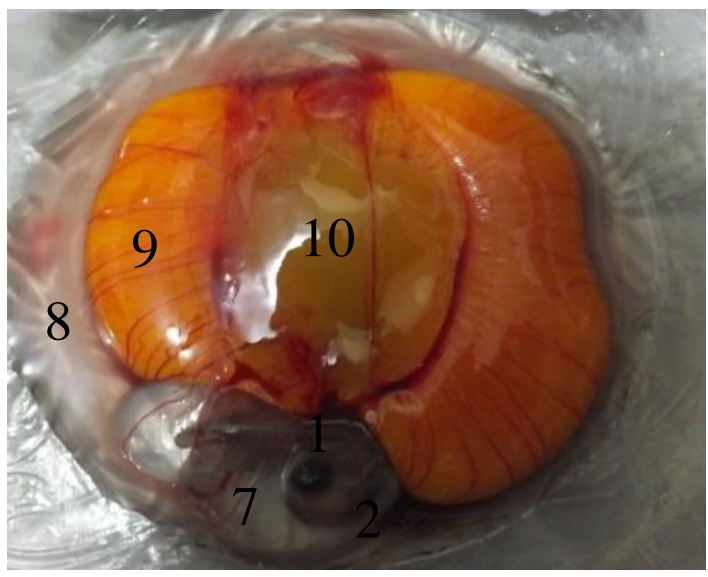

R2

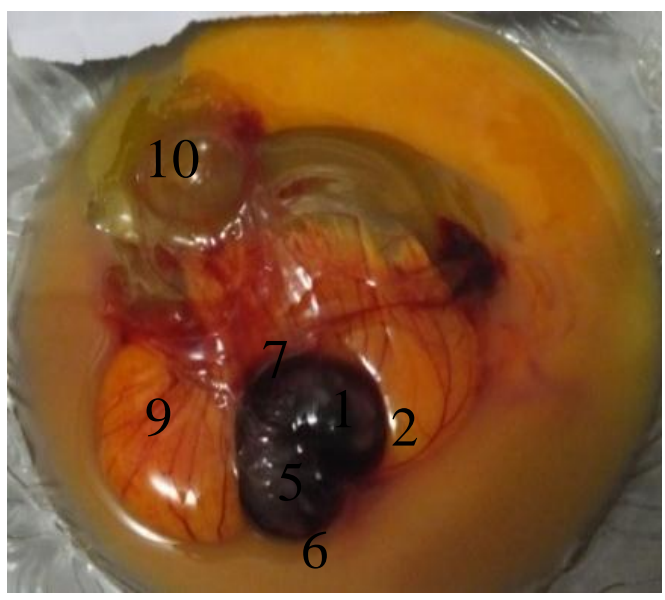

R4

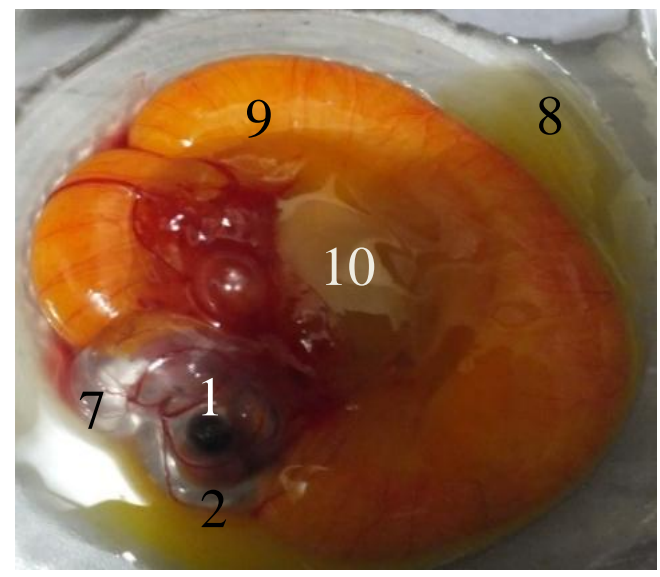

Ket: 1. Mata, 2. Bagian Kepala, 3. Patuk Paruh, 4 sayap, 5. Kaki, 6. Bagian ekor, 7. Amnion, 8. Chorion, 9. Yolk, 10. albumen

Gambar 3. Tahap Perkembangan Embrio R1, R2, R3 dan R4 Umur 12 Hari.

chorion yang disebut chorioallantois. Membrane ini berfungsi sangat penting untuk respirasi embrio dan berfungsi penuh pada hari incubasi ke-12.
Berbanding pengeraman hari ke-11 embrio ayam, sebagian besar albumin dan sebagian kecil kuning telur pertama diserap embrio. 
Tabel 3. Perkembangan embrio itik jawa umur 12 hari

\begin{tabular}{lllll}
\hline Penciri embrio umur 12 hari & R1 & R2 & R3 & R4 \\
\hline$>$ Mata & $\checkmark$ & $\checkmark$ & $\checkmark$ & $\checkmark$ \\
$>$ Bagian kepala & $\checkmark$ & $\checkmark$ & $\checkmark$ & $\checkmark$ \\
$>$ Patuk paruh & $\checkmark$ & $\checkmark$ & $\circ$ & $\circ$ \\
$>$ Sayap & $\checkmark$ & $\circ$ & $\checkmark$ & $\circ$ \\
$>$ Kaki & $\checkmark$ & $\circ$ & $\circ$ & $\circ$ \\
$>$ Folikel bulu halus bagian ekor & $\checkmark$ & $\circ$ & $\circ$ & $\circ$ \\
\hline
\end{tabular}

Pada Tabel 3 diatas dijelaskan bahwa perkembang pada itik jawa hari ke-12 memiliki pertumbuhan pada R1 mata, bagian kepala, patuk paruh, sayap, kaki dan bagian ekor memiliki folokel bulu halus, pada R2 hanya mata, bagian kepala dan patuk paruh yang telihat, R3 bagian kepala, mata dan sayap perkembangan yang terlihat dan R4 hanya mata dan bagian kepala yang terlihat pertumbuhannya. Dibandingkan dengan alabio pada hari ke-12 pada bagian ekor bulu mencapai 2 baris pertumbuhannya dan mandalung pertumbuhan bulu mencapai 2 baris pada bagian ekor terjadi pada hari ke-13 (Nggobe, 2003). Demikian bahwa perkembangan pada bulu pada itik jawa baru terjadi pada R1 seperti dilihat pada gambar dan keterangan di atas bulu baru bertumbuh 1 baris dibagian ekor sedangkan pada R2, R3 dan R4 belum ada pertumbuhan bulu yang terlihat, maka dikatakan itik jawa lebih lambat pertumbuhan bulu dibanding denga alabio dan mandalung. Antara alabio dan mandalung memiliki selisih pertumbuhan bulu 1 hari.

\section{Tahapan Perkembangan Embrio Itik} Umur 16 Hari

Tahapan perkembangan embrio umur 16 hari pada R1, R2, R3 dan R4 yaitu dapat dilihat pada gambar 4 dibawah ini bahwa embrio sudah sangat terbentuk sempurna, bagian punggung sampai ekor sudah tertutupi dengan bulu hitam yang lebat, bagian kepala sudah mulai bertumbuh bulu halus, yolk sudah mulai terserap oleh abdomen, paruk paruh mulai mengeras, kuku kaki sudah terbentuk. Menurut Ngobbe (2003) embrio itik alabio dan mandalung penutupan bulu pada leher bagian ventral terjadi pada hari ke-14 dan ke-16. Dibandingkan dengan kalkun penutupan bulu leher bagian 
R1

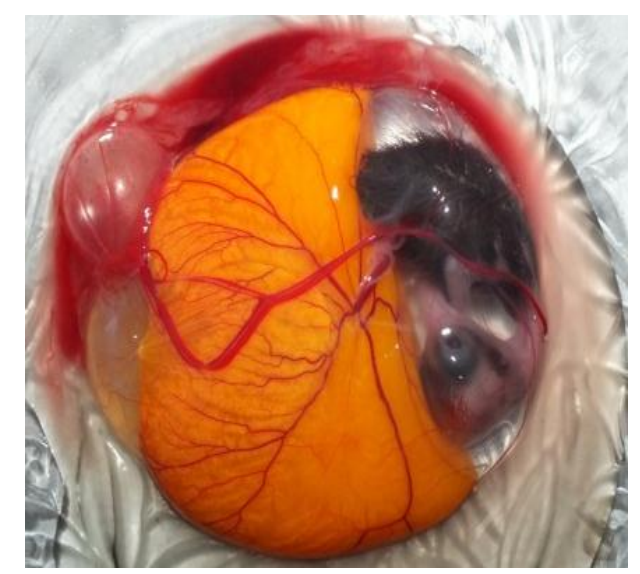

R3

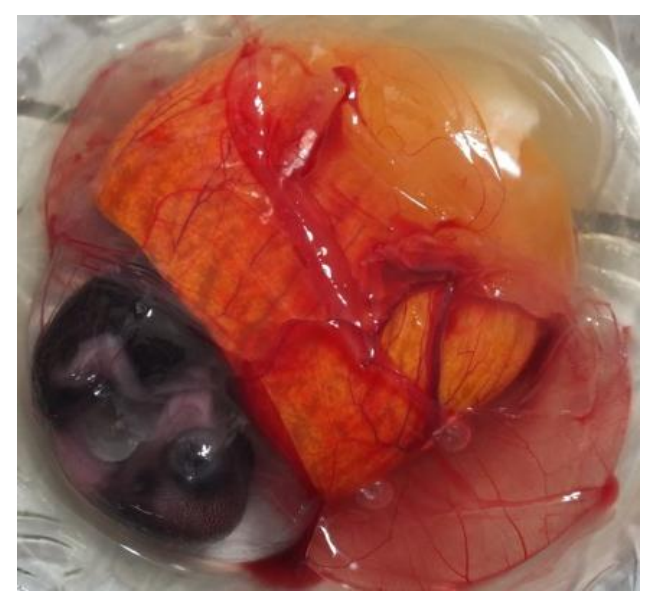

$\mathrm{R} 2$

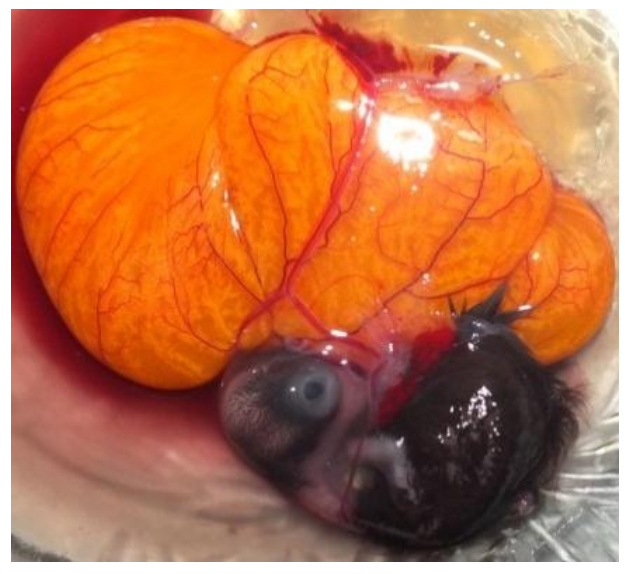

R4

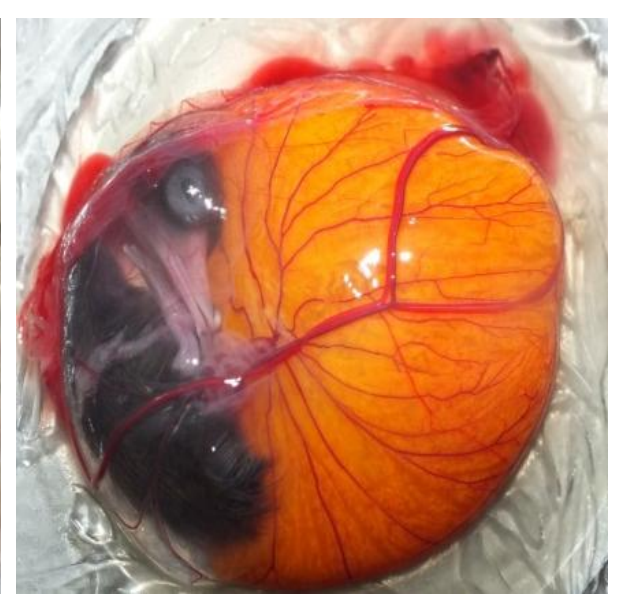

Gambar 4. Tahapan Perkembangan Embrio R1, R2, R3 dan R4 umur 16 Hari

Tabel 4. Perkembangan embrio itik jawa umur 16 hari

\begin{tabular}{ccccc}
\hline Penciri embrio umur 16 hari & R1 & R2 & R3 & R4 \\
\hline$>$ Buluh tumbuh 4 baris di radius/ulna & $\checkmark$ & $\checkmark$ & $\checkmark$ & $\checkmark$ \\
$>$ Buluh tumbuh 2 baris di mekapus & $\checkmark$ & $\checkmark$ & $\checkmark$ & $\checkmark$ \\
$>$ Bulu menutup seluru bagian dada & $\checkmark$ & $\checkmark$ & $\checkmark$ & $\checkmark$ \\
$>$ Bulu menutupi daerah mekapus & $\checkmark$ & $\checkmark$ & $\checkmark$ & $\checkmark$ \\
\hline
\end{tabular}


ventral terjadi pada hari ke-12 (Phillips dan Williams, 1994). Dengan demikian perbandingan dengan kalkun, perkembangan alabio dan mandalung terlambat 2 dan 4 hari. Pertumbuhan bulu yang lambat pada itik mandalung kemungkinan dipengaruhi oleh sifat yang diwarisi dari entok, karena sebagaimana diketahui bahwa entok mempunyai sifat pertumbuhan bulu yang lambat, sedangkan itik mewarisi sifat pertumbuhan bulu yang cepat.

Pada Tabel 4 diatas, menjelaskan bahwa tumbuhnya bulu pada itik jawa dimulai dari hari ke-16 bulu menutupi sampai mekapus. Dibandingkan dengan itik alabio penutupan bulu sampai mekapus terjadi dihari ke-19 sedangkan pada mandalung terjadi dihari 22 (Ngobbe, (2013). Menurut Phillips dan Williams (1994) pada kalkun penutupan buluh sampai vental terjadi pada hari ke-12. Dengan demikian dapat dikatan bahwa embrio itik jawa lebih lambat 4 hari dibanding kalkun, alabio lebih lambat 3 hari, mandalung lebih lambat 5 hari.sedangkan mandalung lebih lambat 2 hari dari alabio.

\section{Tahapan Perkembangan Embrio Itik Umur 20 Hari}

Pada pengamatan tahapan perkembangan embrio R1, R2, R3 dan R4 umur 20 hari dapar dilihat pada gambar 5 dibawah ini yaitu embrio sudah terbentuk anak itik, kaki sudah menjadi warna hitam, bagian ujung patuh paru berwarna hitam dan sudah keras, bulu hitam yang lebat sudah menutupi seluruh tubuh, yolk sudah hampir terserap oleh abdomen.

Pada Tabel 5 diatas dijelaskan bahwa pada itik jawa diawali dengan terbentuknya lubang hidung dan tonjolan kecil di atas paruh terjadi pada hari ke-20. Dibandingan dengan (Nggobe, 2013) yang menjelaskan pertumbuhan pada alabio yaitu terbentuknya tonjolan kecil dan lubang hidung terjadi hari ke 14 sampai 22 dan mandalung terjadi pada hari ke 16 sampai 26. Hal ini berarti bahwa dari terbentuknya lubang hidung dan tonjolan kecil pada itik jawa lebih cepat pertumbuhan tonjolan kecil pada alabio 6 hari dan lebih lambat pertumbuhan lubang hidung 2 hari. Sedangkan pada mandalung lebih cepat pertumbuhan tonjolan kecil 4 hari dan pertumbuhan lubang hidung lebih lambat 6 hari dari itik jawa. 
R3

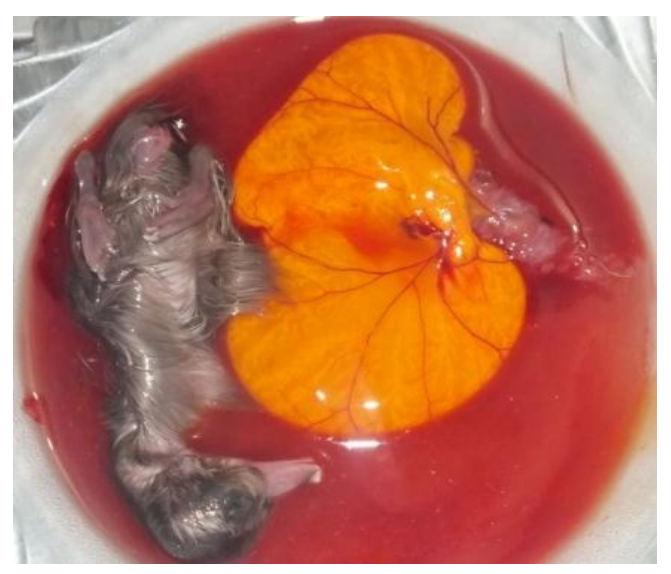

R1

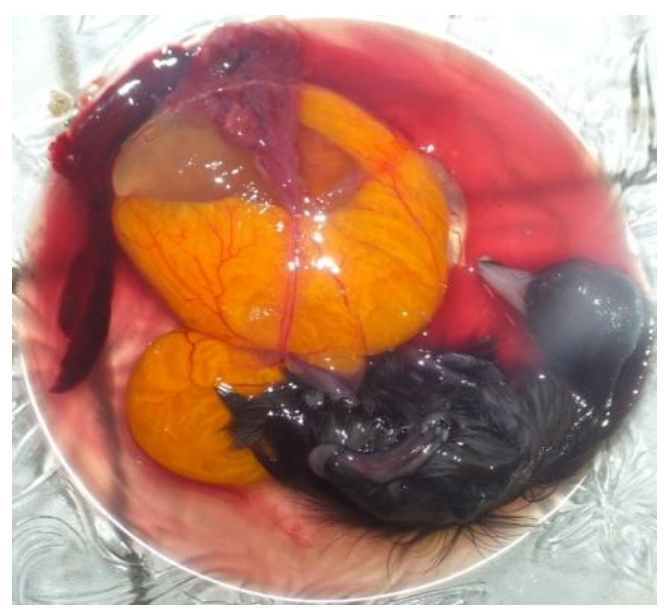

R4

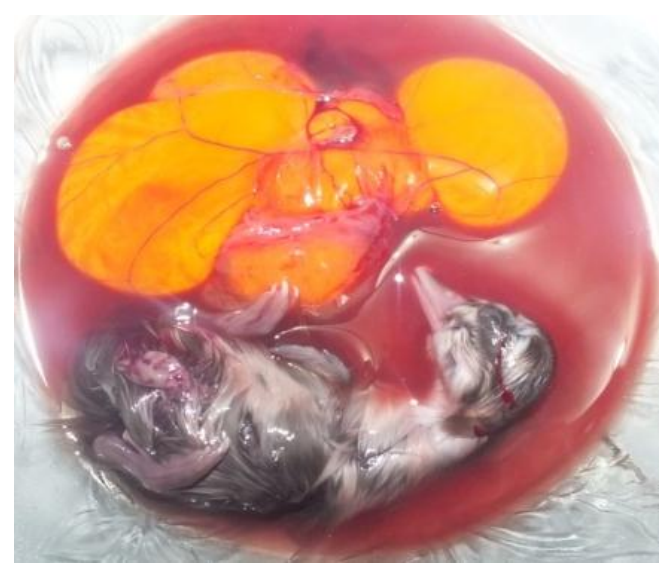

R2

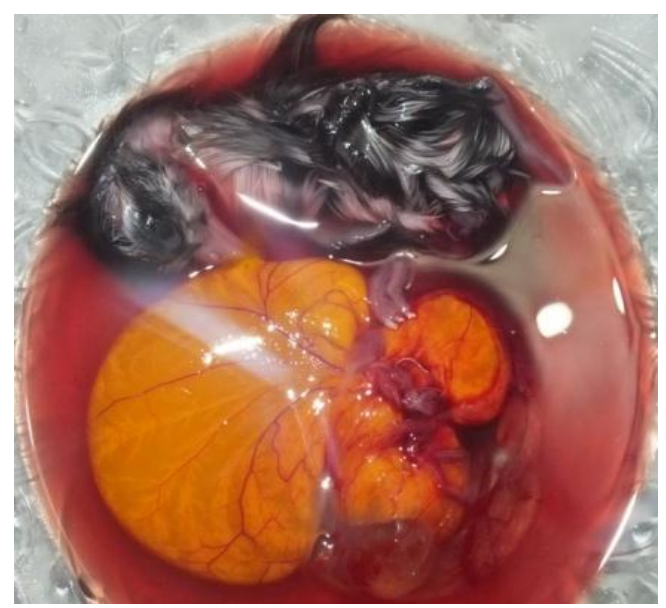

Gambar 5. Tahapan Perkembangan Embrio R1, R2, R3 dan R4 umur 20 Hari

Tabel 5. Perkembangan embrio itik jawa umur 20 hari

\begin{tabular}{ccccc}
\hline Penciri embrio umur 20 hari & R1 & R2 & R3 & R4 \\
\hline$>$ Terbentuknya tonjolan kecil (nasal pits) & $\checkmark$ & $\checkmark$ & $\checkmark$ & $\checkmark$ \\
$>$ Lubang hidung terlihat jelas & $\checkmark$ & $\checkmark$ & $\checkmark$ & $\checkmark$ \\
\hline
\end{tabular}


Tahapan Perkembangan Embrio Itik Umur 24 Hari

Pada tahapan perkembangan embrio umur 24 hari yaitu dapat dilihat pada gambar 6 dibawah ini bahwa perkembangan keempat perlakuan $\mathrm{R} 1, \mathrm{R} 2$, R3, dan R4 yaitu sama embrio sudah

R1

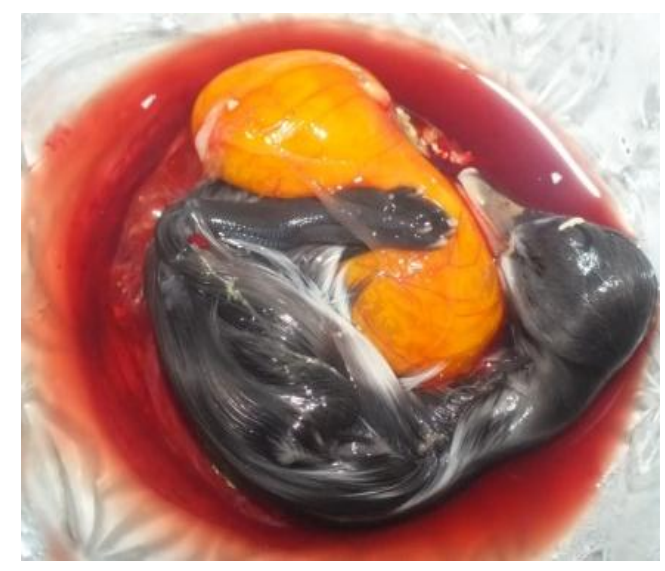

R3

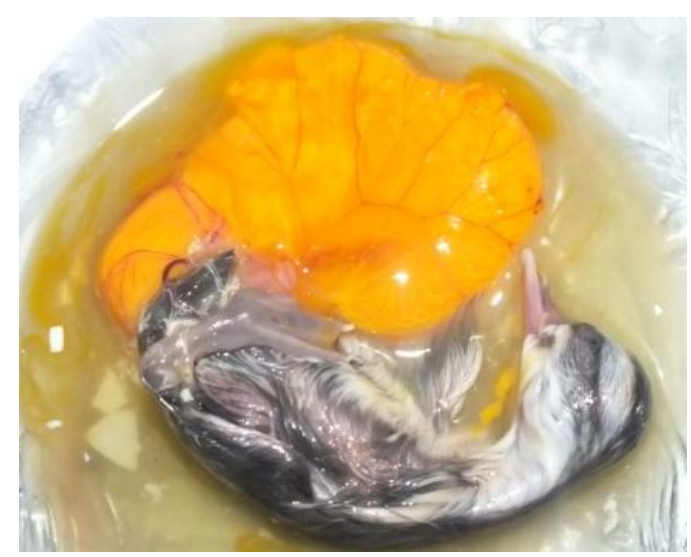

menjadi anak itik dan terbentuk sangat sempurna tinggal menunggu waktu untuk menetas, yolk semakin mengecil karena sudah hampir terserap habis oleh abdomen, hanya saja pada R1 dan R3 ada sedikit perbedaan warna bulu karena pada R1 dan R3 warna buluh bercampur putih.

\section{$\mathrm{R} 2$}

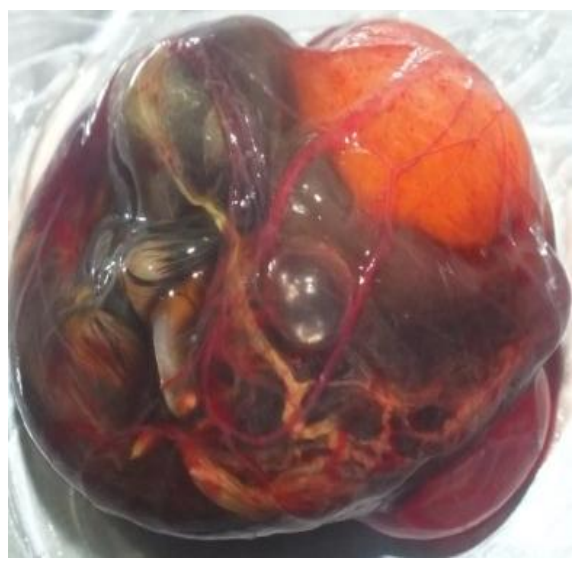

$\mathrm{R} 4$

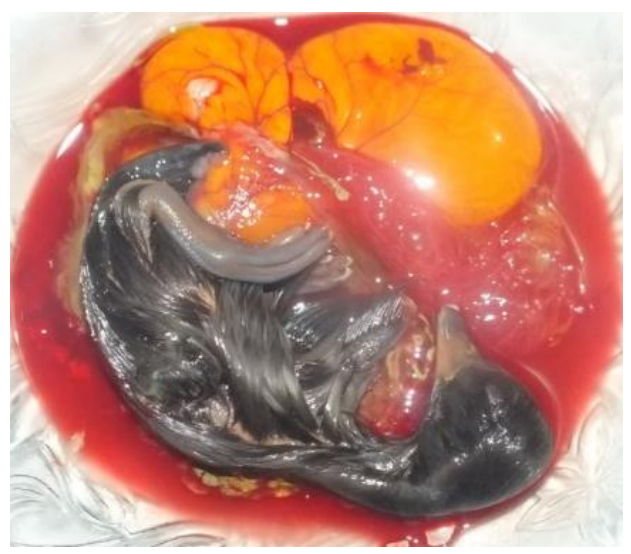

Gambar 6. Tahapan Perkembangan Embrio R1, R2, R3 dan R4 umur 24 Hari

Tabel 6. Perkembangan embrio itik jawa umur 24 hari

\begin{tabular}{ccccc}
\hline Penciri embrio umur 24 hari & R1 & R2 & R3 & R4 \\
\hline$>$ Hilangnya homy bill di paruh bawah & $\checkmark$ & $\checkmark$ & $\checkmark$ & $\checkmark$ \\
$>$ Gigi telur mencapai ujung paruh & $\checkmark$ & $\checkmark$ & $\checkmark$ & $\checkmark$ \\
\hline
\end{tabular}


Seperti dilihat pada Tabel 6 bahwa pada itik jawa hilanya homy bill diparuh bawah dan gigi telur mencapai ujung paruh terjadi hari ke-24. Dibanding dengan alabio hilangnya homy bill diparuh bagian bawah terjadi pada hari ke-20 sedangkan pada mandalung terjadi pada hari ke-24, dan terbentuknya gigi telur mencapai ujung paruh pada alabio terjadi pada hari ke-25 dan pada mandalung terjadi pada hari ke29. Dari tahapan hilangnya homy bill dibawah paruh pada itik jawa lebih lambat 4 hari pertumbuhannya dari alabio, dan pada mandalung memiliki pertumbuhan yang sama, dan pertumbuhan gigi telur mencapai ujung paruh pada alabio terjadi pada hari ke-24 dan pada mandalung terjadi hari ke-28. Dari perbandingan dengan alabio memiliki pertumbuhan waktu yang sama dan pada mandalung lebih lambat 4 hari.

\section{Pengaruh Bobot Telur Terhadap Fertilitas}

Fertilitas yang dihasilkan pada bobot telur R1 $(55 \mathrm{~g} \leq \mathrm{BT}<60 \mathrm{~g})$, R2 (61g $\leq \mathrm{BT}<65 \mathrm{~g}), \mathrm{R} 3(65 \mathrm{~g} \leq \mathrm{BT}<70 \mathrm{~g})$ danR4 $(71 \mathrm{~g} \leq \mathrm{BT}<75 \mathrm{~g})$. Persentase Telur itik 85\%-90\% disajikan pada Tabel 7 yang ada pada Bobot Telur. Berdasarkan penelitian yang dilakukan diperoleh kisaran persetase fertilitas yang tinggi antara 85\% - 90\%. Hasil ini sejalan dengan penelitian
Dewanti et al. (2014) bobot telur 53g - 76g fertilitasnya adalah $83,73 \%$ - 89,70\%. Hasil dari fertilitas yang diperoleh masih pada kisaran nilai rata-rata yang baik. Data hasil penelitian menunjukan bahwa fertilitas dari perlakuan R2 - R4 persentasenya tidak berbeda jauh meskipun dari data yang ada menunjukan fertilitas tertinggi terdapat pada R1 dan R3, dan terendah terdapat pada R2. Rendahnya fertilitas pada R2 kemungkinan disebabkan karena adanya telur yang ditetaskan dalam keadaan yang kurang baik.

Hasil analisi ragaman menunjukan bahwa perlakuan memberikan pengaruh yang tidak nyata $(\mathrm{P}>0,05)$ terhadap persentase fertilitas pada tiap perlakuan. Hal ini diduga karena lama penyimpanan telur mungkin memiliki waktu yang tidak jauh. Penelitian ini sejalan dengan pendapat Susanti et al. (2015) yang menjelaskan bahwa fertilitas telur unggas yang tidak berbeda nyata ini diduga karena lama penyimpanan telur yang ditetaskan memiliki interval waktu yang sama yaitu 2 hari. Menurut Susanti et al. (2015) lama penyimpanan telur memiliki peranan penting dalam menjaga kualitas telur.

Menurut Setioko et al. (1999), fertilitas telur itik Alabio adalah sebesar $95,57 \%$, sedangkan dilaporkan Suryana 
dan Tiro (2007), hasil fertilitas yang diperoleh selama 26 periode penetasan telur itik Alabio sebesar 90,38\%. Purba et al. (2005) menyatakan bahwa rata-rata fertilitas telur itik di daerah sentra produksi dan penetasan di Kabupaten Blitar, Jawa Timur berkisar antara 86,46\% $-90,49 \%$.

Faktor-faktor yang mempengaruhi fertilitas telur adalah rasio jantan dan betina, pakan induk, umur pejantan yang digunakan dan umur telur, jumlah induk yang dikawini oleh satu pejantan dan umur induk (Solihat et al., 2003). Selain itu, hubungan temperatur lingkungan yang semakin meningkat antara lain temperatur atmosfir disinyalir dapat menyebabkan penurunan fertilitas atau sebaliknya. Selain itu, menurut Rahayu et al. (2005) fertilitas sangat dipengaruhi oleh beberapa faktor lain antara lain iklim, bangsa atau varietas ayam, sistem perkawinan, Menurut Budi et al. (2008); Suryani et al. (2012) pakan juga sangat berpengaruh pada fertilitas telur, kesehatan, umur induk, pengelolaan telur sebelum masuk mesin tetas termasuk pemilihan bobot telur tetas dan penyimpanan telur tetas (Zakaria, 2010 dalam Ngobbe, 2003), dan pengelolaan telur selama penetasan. King'ori (2011) mengemukakan bahwa ada beberapa hal yang mempengaruhi gagalnya telur fertil untuk menetas. Faktor tersebut diantaranya adalah nutrien di dalam telur dan kondisi yang tidak memungkinkan untuk perkembangan embrio. Faktor lain yang mempengaruhi fertilitas diantaranya adalah nutrien, motilitas sperma, dan persentase sel sperma yang abnormal atau mati. Faktor nutrient misalnya kekurangan vitamin $\mathrm{E}$ dalam pakan dapat menyebabkan telur menjadi tidak fertil.

Menurut Susanti et al. (2015) penelitian ini fertilitas telur ayam arab dengan lama penyimpanan 2, 4, dan 6 hari yaitu $77,78 \%, 59,26 \%$, dan70,73\% relatif rendah dari pada penelitian Adnan (2010) yaitu 76,70 - 93,33\%. Hal ini disebabkan oleh jumlah telur yang busuk dan pecah pada mesin tetas. Telur yang busuk dan pecah pada lama penyimpanan 2 dan 6 hari lebih sedikit dibandingkan dengan lama penyimpanan 4 hari. Hal ini kemungkinan disebabkan oleh adanya keretakan pada kerabang telur yang menyebabkan poripori kerabang telur semakin lebar sehingga memungkinkan telur terkontaminasi oleh mikroorganisme. Keretakan yang terjadi diduga sangat halus sehingga keretakan tidak dapat dideteksi pada saat candling. 
Tabel 7. Rataan Pengaruh bobot telur terhadap bobot tetas dan persentase fertilitas

\begin{tabular}{lllll}
\hline \multirow{2}{*}{ Parameter } & \multicolumn{4}{c}{ Perlakuan } \\
\cline { 2 - 5 } & $\mathrm{R} 1$ & $\mathrm{R} 2$ & $\mathrm{R} 3$ & $\mathrm{R} 4$ \\
\hline Bobot Tetas (g) & 33,13 & 38,77 & 42,20 & 48,28 \\
Fertilitas (\%) & 90 & 85 & 90 & 87.5 \\
\hline
\end{tabular}

\section{Pengaruh bobot telur terhadap bobot} tetas

Bobot tetas yang dihasilkan yaitu $33.13 \mathrm{~g}-48,28 \mathrm{~g}$ disajikan pada Tabel 7. Berdasarkan penelitian yang dilakukan diperoleh rata-rata bobot tetas antara $31 \mathrm{~g}$ 51g. Bobot telur tetas 55g - 60g menghasilkan reratahan bobot DOD yang paling rendah yaitu $33,13 \mathrm{~g}$ sedangkan bobot telur $71 \mathrm{~g}-75 \mathrm{~g}$ menghasilkan bobot DOD sebesar 48,28g. hal ini menunjukan bahwa ada korelasi antara bobot telur dengan bobot tetas, karna semakin besar bobot telur maka bobot DOD yang dihasilkan juga semakin besar. Pendapat ini sejalan dengan penelitian Salombe (2012), yang menunjukkan rata-rata bobot tetas 30,25g dan 31,41g. Hermawan (200), dan Petek et al. (2003) yang menyatakan bahwa ada hubungan yang sangat nyata antara bobot telur dan bobot tetas. Pada penelitian ini semakin besar bobo telur maka semakin besar bobot DOD yang dihasilkan. Hal ini kemungkinan berhubungan dengan keberadaan nutrient yang terkandung dalam telur. Semakin besar bobot telur maka semakin besar kandungan nutrient yang ada dalam telur sehingga besar pula kesempatan embrio untuk menyerap nutrient yang ada dalam telur tetas. Menurut Pattison (1993) telur banyak mengandung nutrient seperti vitamin, mineral dan air yang dibutuhkan untuk perkembangan embrio selama inkubasi serta digunakan juga sebagai cadangan makanan.

Menurut Hassan et al. (2005), bobot tetas berkorelasi positif dengan bobot telur tetas. Semakin besar bobot telur tetas maka semakin besar pula bobot tetas yang dihasilkan. Perbedaan yang nyata ini diduga disebabkan oleh perbedaan jumlah kuning telur dan putih telur sebagai sumber nutrisi selama perkembangan embrio. Bobot telur tinggi mengandung jumlah kuning telur dan putih telur tinggi. Semakin banyak kuning telur dan putih telur maka ketersediaan nutrisi untuk perkembangan embrio semakin banyak, sehingga bobot tetas yang dihasilkan akan lebih besar. Adapun faktor yang berpengaruh terhadap bobot DOC diantaranya, pakan dan kualitas telur (Yousefi dan Karkodi, 2007), umur induk, 
dan pengelolaan penetasan (Bachari, 2006). Hasil ini mengindikasikan bahwa guna mendapatkan ayam kampung dengan bobot DOC yang tinggi dapat diawali dengan melakukan seleksi terhadap bobot telur, dan telur yang paling baik adalah telur yang mempunyai bobot di atas 39,00g. Sedangkan menurut Rajab (2013) dari hasil penelitian hubungan antara bobot telur tetas dengan bobot DOC ayam kampung bahwa bobot telur mempunyai hubungan yang sangat nyata dengan bobot DOC ayam kampong dan sangat tinggi yaitu sebesar 91,8\%. Hal ini berarti bahwa makin besar telur tetas akan mempunyai bobot DOC yang baik pula.

\section{KESIMPULAN}

Berdasarkan hasil penelitian maka didapatkan kesimpulan yaitu bobot telur tidak berpengaruh pada proses perkembangan embrio dan fertilitas, tetapi berpengaruh terhadap bobot tetas DOD.

\section{DAFTAR PUSTAKA}

Adnan, M. 2010. Pengaruh lama penyimpanan telur ayam buras terhadap fertilitas, daya tetas telur dan berat tetas. Jurnal Agrisistem, Vol 6 (2) : 1858 4330

Anonimous. 2016. perkembangan embrio dari hari kehari. https://www.ciptapangan.com/files/d ownloadsmodule/
@ random4413d85398188/11859534 10_buletin_maret_2007.pdf. Diakses 1 november 2016.

Bachari, I., I. Sembiring, dan D. S. Tarigan. 2006. Pengaruh frekuensi pemutaran telur terhadap daya tetas dan bobot badan DOC ayam kampung. Jurnal Agribisnis Peternakan 2:101-105

Baruah, K.K., P.K. Sharma dan N.N, Bora. 2001. Fertility, hatchability and embryonic mortality in ducks. J. IndianVeteterinary 78:529-530.

Budi, U., I. Bachari, dan P. R. Lisma. 2008. Penambahan tepung cangkang telur ayam ras pada ransum terhadap fertilitas, daya tetas dan mortalitas Burung Puyuh. Jurnal Agribisnis Peternakan 4: 111-115.

Dewanti, R., Yuhan, dan Sudiyono. 2014. Pengaruh bobot dan frekuensi pemutaran telur terhadap fertilitas, daya tetas, dan bobot tetas itk local. Buletin Peternakan Vol. 38(1):16-20.

Hermawan, A. 2000. Pengaruh bobot dan indeks telur terhadap jenis kelamin anak ayam kampung saat menetas. Skripsi. Fakultas Peternakan. Institut Pertanian Bogor. Bogor.

Hassan, S. M., A. A. Siam, M. E. Mady and A. L. Cartwright. 2005. Egg storage period and weight effect on hatchability of Ostrich (Struthio camelus) eggs. Poult. Sci. 84: 19081912.

Jull, M.A. 1951. Poultry Breeding. 2 1st Edition Mc Graw-Hill Book Company. New York. 
King'ori, A. M. 2011. Review of the factors that influence egg fertility and hatchability in Poultry. Int. J. Poult. Sci. 10: 483-492.

Lembong, J. E., 2015. Analisis break even point usaha ternak itik pedaging (studi kasus pada usaha itik milik kelompok masawang di Desa Talikuran Kecamatan Remboken). Jurnal Zootek. Vol. 35 No. 1 : 39-45.

Neishem Mc, Austic RE dan Card LE. 1997, Poultry Prodaction Lea and Febinger. Philadelphia.

Nggobe M. 2003. Perkembangan Bobot Dan Penampilan Embrio Itik Alabio Dan Hasil Persilanganya Dengan Entok Jantan Sebagai Pedoman Untuk Menduga Umur Embrio. Tesis. Sekolah Pascasarjana Institut Pertanian Bogor.

Pattison, M. 1993. The Health of Poultry. Longman Scientific and Technical. Harlow.

Peebles, E. D., T. Zumwalt, S. M. Doyle, P. D. Gerrard, M. A. Latour, C. R. Boyle, \& T. W. Smith. 2001. Breeder age influence on embryogenesis in broiler hatching aggs. J. Poult. Sci. 80:272-277.

Petek, M., H. Baspinar and M. Ogan. 2003. Effect of eggs weight and length of storage on hatchability and subsequent growth performance of Quail. S. Afr. J. Anim. Sci. 33: 242247.

Phillips RE, Williams CS. 1994. External morphology of the turkey during the incubation. Poultry Sci 19: 396-400. Purba M., P.S. Hardjosworo, L.H.
Prasetyo, D.R. Ekastuti. 2005. Pola Rontok Bulu Itik Alabio Betina Dan Mojosari Serta Hubungannya Dengan Kadar Lemak Darah (Trigliserida); Produksi dan Kualitas Telur. Jurnal Ilmu Ternak dan Veteriner 10 (2): 96-105.

Rahayu, I. H. S., I. Suherlan, dan I. Supriatna. 2005. Kualitas telur tetas ayam Merawang dengan waktu pengulangan insiminasi buatan yang berbeda. J. Indo. Trop. Anim. Agric. 30. (3):

Rajab, A. 2013. Hubungan bobot telur dengan fertilitas, daya tetas dan bobot anak ayam kampong. Jurnal Agrinimal. Vol. 3: 56-60.

Setioko, A.R. dan Istiana. 1999. Pembibitan itik Alabio di Kabupaten Hulu Sungai Tengah. Prosiding Seminar Nasional Peternakan dan Veteriner. Jilid I; Bogor,1-2 Desember 1999. Pusat Penelitian dan Pengembangan Peternakan. Badan Penelitian dan Pengembangan Pertanian. Bogor. hlm. 382-387

Solihat, S. Suswoyo dan I. Ismoyowati. 2003. Kemampuan Performan Produksi Telur Dari Berbagai Itik Lokal. Jurnal Peternakan Tropis 3 (1):27-32.

Setioko, A.R., S. Sopiyana, dan T. Sunandar. 2005. Identifikasi Sifat Kuantitatif dan Ukuran Tubuh Pada Itik Tegal, Itik Cirebon dan Itik Turi. Prosd. Seminar Nasional Peternakan dan Veteriner. Pusat Penelitian dan Pengembangan Peternakan. Badan Penelitian dan Pengembangan Pertanian. Bogor. Hal:786-794 
Suryana dan B.W. Tiro. 2007. Keragaan Penetasan Telur Itik Alabio Dengan Sistem Gabah Di Kalimantan Selatan. Di dalam; Percepatan Inovasi Teknologi Pertanian Spesifik Lokasi Mendukung Kemandirian Masyarakat Kampung di Papua. Prosd. Seminar Nasional dan Ekspose. Balai Pengkajian Teknologi Pertanian Papua; Jayapura, 5-6 Juli 2007. Balai Besar Pengkajian dan Pengembangan Teknologi Pertanian. Badan Penelitian dan Pengembangan Pertanian. Bogor. Hal: 269-277

Salombe, J. 2012. Fertilitas, Daya Tetas, dan Berat Tetas Telur Ayam Arab pada Berat Telur yang Berbeda. Skripsi. Fakultas Peternakan. Universitas Hasanuddin. Makasar.

Suryani, N., N. Suthama dan H. I. Wahyuni. 2012. Fertilitas telur dan mortalitas embrio ayam kedu pebibit yang diberi ransum dengan peningkatan nutrien dan tambahan Sacharomyces cerevisiae. Animal Agricultural Journal 1: 389-404.

Sari, D. M. 2013. Perkembangan Embrio Dan Daya Tetas Serta Viabilitas Anak Ayam Arab Dari Umur Induk Yang Berbeda. Skripsi. Fakultas Peternakan. Institut Pertanian Bogor. Bogor.

Susanti, I. T. Kurtini, dan D. Septinova. 2015. Pengaruh lama penyimpanan terhadap fertilitas, susut tetas, daya tetas dan bobot tetas telur ayam arab. Jurnal Ilmiah Peternakan Terpadu Vol. 3(4): 185-190.
Winter AR dan Fuck EM. 1956. Poultry Science and Practice. $4{ }^{\text {rd }}$ Edition. JB Lippincot Company Chicago, Philadelphia, New york

Zakaria, M.A.S. 2010. Pengaruh lama penyimpanan telur ayam buras terhadap fertilitas, daya tetas telur dan berat tetas. Jurnal Agrisistem 6: 97-103.

Yousefi, M. dan K. Karkodi. 2007. Effect of probiotic thepax ${ }^{\circledR}$ and Saccharomyces cerevisiae supplementation on performance and egg quality of laying hens. Journal International Poultry Science 6: 5254. 